\title{
DETERMINANTS OF CLIMATE CHANGE MITIGATION AND ADAPTATION STRATEGIES: AN APPLICATION OF PROTECTION MOTIVATION THEORY IN KONTA DISTRICT, SOUTH WESTERN ETHIOPIA
}

\author{
DEREJE TESEMA REGASA, NEGA ABERA AKIRSO \\ Department of Sociology, Jimma University, Ethiopia
}

(C) 2019 Dereje Tesema Regasa and Nega Abera Akirso

This is an open access article distributed under the Creative Commons Attribution-NonCommercial-NoDerivs license (http://creativecommons.org/licenses/by-nc-nd/3.0/)

DOI: $10.1515 /$ eras-2019-0010

\begin{abstract}
Climate change becomes a widely acknowledged and inevitable global challenge of $21^{\text {st }}$ century. For developing countries like Ethiopia, it intensifies existing challenges of ensuring sustainable development. This study examined factors affecting climate change adaptation and mitigation strategies by taking in Protection Motivation Theory. The study draws on mixed research approach in order to assess the subjective understanding about climate change threats and identify the factors determining responses to climate change. While qualitative data were collected through focus group discussions and interviews, quantitative information was collected using semi structured survey from 296 randomly selected farmers from different agro-ecologies. Qualitative data was dominantly analyzed using content analysis while descriptive and inferential statistics were applied to analyze quantitative data. Almost all respondents $(97 \%)$ perceived that climate change is occurring and threatening their wellbeing. Dwindling precipitation, increasing temperature and occurrence of human and animal disease were perceived to represent climate change. From nationally initiated strategies, farmers were found to largely practice soil and water conservation and agricultural intensification, which they perceived less costly and compatible to their level of expertise. The result of binary logistic regression revealed that perceived severity of climate change, perceived susceptibility to climate change threat, perceived own ability to respond, response efficacy and cost of practices predicted farmers motivation to practice climate change adaptation and mitigation strategies. Thus, building resilient system should go beyond sensitizing climate response mechanisms. Rural development and climate change adaptation policies should focus on human capital development and economic empowerment which would enable farmers pursue context specific adaptation and mitigation strategies thereby maintain sustainable livelihood.
\end{abstract}

\section{Keywords}

adaptation, belief, climate change, efficacy, mitigation, severity, vulnerability

\section{Introduction}

Global climate is increasingly changing (UNFCC 2007). No region or country is immune to its impacts; however, the extent of vulnerability differs widely. Climate change involves long-term change and significant variation in temperature, precipitation and wind pattern (IPCC 2007; Feleke, Berhe, Gebru \& Hoag, 2016; Yéo, Goula, Diekkrüger \& Afouda, 2016). Mounting surface temperature and global sea level in the last few decades are a major aspect of climate change (Rahmstorf, Foster \& Cahill, 2017). Though natural factors have caused climate change at different point in Earth's history, anthropogenic variables are recognized as primary factors since the industrial revolution period (Aizebeokhai, 2009; 
Asayehegn, Temple, Sanchez \& Iglesias, 2017). Global warming becomes unequivocal due to the increasing proportion of greenhouse gases in the atmosphere. This is partly attributed, among others, to burning fossil fuel, industrial activities, land use change and clearing forest among others (Ajuang, Abuom, Bosire, Dida \& Anyona, 2016; Elum, Modise \& Marr, 2016).

Though climate change discourse is debatable regarding its existence and causes, increasing in temperature becomes unambiguous (Aizebeokhai, 2009; Hunt \& Watkiss, 2011). Concentrations of carbon dioxide increased from a pre-industrial value of 278 parts per million to 379 parts per million in 2005 , and the average global temperature rose by $0.74^{\circ} \mathrm{C}$ (UNFCC 2007). The trend is projected to rise than ever (Rahmstorf et al., 2017). The earth is expected to warm by about $2-3{ }^{\circ} \mathrm{C}$ by the end of the $21^{\text {st }}$ century (Ajuang et al., 2016). Climate change and associated global warming poses serious consequences on biodiversity and proved to have intricate short and long-term consequences on the world population (Huq, Hugé, Boon \& Gain, 2015).

Ramifications of climate change are not evenly distributed across the globe (Harun, Jamalani, Elawad \& Fallah, 2014). In developing countries, large proportion of population bears severe consequences of climate change due to pursuing rain-fed agriculture that heavily depends on climate pattern (Harun et al., 2014; Temesgen, Yehualashet \& Rajan, 2014). Evidences show that smallholder farming in developing regions are the most vulnerable livelihood to climate change (Abrha \& Simhadri, 2015a; Alam, Alam \& Mushtaq, 2017; Berhe et al., 2017). The effect of climate change is heightened in sub-Saharan Africa partly due to low coping capabilities, poor preparedness and weak institutional capacity of detecting early warning (Debela, Mohammed, Bridle, Corkrey \& Mcneil, 2015; M.M, 2014). Consequently, increasing global warming easily affects the rainfall pattern, causes flooding and drought, thereby contributing to production failure and related humanitarian crisis in the continent (Kibue et al., 2015). In the tropical countries, in addition to changing land use pattern, the impact of climate change contributes to significant water discharge fluctuation thereby affecting millions of lives (Tarigan \& Faqih, 2019).

Climate risk is an inherent feature of the Ethiopian agriculture based economy (Suryabhagavan, 2017). In Ethiopia, rained agriculture is the main source of living; it supports the livelihood of more than $80 \%$ of the overall population. The sector also makes about $49 \%$ of Ethiopian GDP (Gross Domestic Product) and generates more than $80 \%$ of the foreign exchange (Deressa, 2008; Feleke et al., 2016; Temesgen et al., 2014). Recurrent drought appeared as the most critical climate induced hazard affecting the country and resulted in loss property and lives (Wako, Tadesse \& Angassa, 2017). Since the agriculture is predominantly rain-fed, drought was reported to shrink agricultural production which in turn resulted in food insecurity of large population each production year (Belay, Recha, Woldeamanuel \& Morton, 2017; Tazeze, Haji \& Assistance, 2012). Worrying is that adverse climate effects were projected to increase and compromise agricultural yield, which is already low (Feleke et al., 2016). This necessitated measures that help to reduce the severe impacts of climate change (UNFCC 2007).

Climate change mitigation and adaptation are considered as vital mechanism to reduce the adverse impacts of climate change (IPCC 2007). While adaptation involves taking adjustment measures to reduce the adverse effects of climate change, mitigation entails tackling the effects of climate change by reducing the emissions of Green House Gas (GHG) (Limantol, Keith, Azabre \& Lennartz, 2016; Shikuku et al., 2017). Mitigation is considered as a crucial long-term solution to addressing ongoing climate change and minimizing its negative impacts in the future (IPCC 2011; Erena, 2016). Since mitigation cannot reverse the already changed climate, investment on adaptation is vital (Locatelli, 2011). Adaptation to climate change appeared as the most important strategy in enhancing resilience of farming systems in Africa (Asayehegn et al., 2017). However, adaptation is inadequate in itself without robust planning 
on mitigation measures (Elum et al., 2016; Hunt \& Watkiss, 2011). Thus, mitigation and adaptation are not substitutable, but one complements the other.

\section{Problem Statement}

Climate change is becoming inevitable. Consequently, the importance of adaptation to climate change attracted the attention of many researchers across the world. Need for adaptation is higher among developing countries where vulnerability is presumably higher (Deressa, 2008; Elum et al., 2016). Plethora of literature addressed perception of farmers about climate change (Abrha \& Simhadri, 2015b; Alam et al., 2017; Asrat \& Simane, 2018a; Harun et al., 2014; Limantol et al., 2016; Shikuku et al., 2017; Wako et al., 2017) and determinants of adaptation strategies (Abrha \& Simhadri, 2015a; Amare \& Simane, 2017; Belay et al., 2017; Berhanu \& Beyene, 2015; Falco, n.d.; Feleke et al., 2016; Mubaya \& Mafongoya, 2017; Shikuku et al., 2017; Tesso, Emana \& Ketema, 2012; Yesuf, 2008). As part of implementing Climate Resilient Green Economy (CRGE), Ethiopia has adopted adaptation and mitigation strategies to respond to climate change risks. Adaptation and mitigation practices, however, are unevenly distributed (Alam et al., 2017; Asayehegn et al., 2017). Among others, farmers' perception about causes of climate change and adaptation strategies is important in understanding farmers' differential ability in practicing adaptation strategies. Adaptation strategies are less effective without understanding farmers' perception about climate change. Factors which farmers perceive cause climate change largely influence their adaptation behavior.

Previous studies have concentrated on determinants of adaptation strategies rather than integrating mitigation measures practiced by farmers. Existing studies about determinants of climate change adaptation in Ethiopia are limited to verifying the effects of socio-demographic and economic variables pertaining to adaptation strategies. This study, however, employs psychometric approach and scrutinizes micro-behaviors that determine not only adaptation but also the complementing strategy, mitigation strategies. How do farmers perceive climate change and its causes? So, how they are attempting to respond changes in climate? Are farmers informed enough to mitigate the effects of climate change beforehand or take adjustment measures in the human-environment system in response to actual and/or anticipated different climatic conditions? Why some farmers adopt nationally endorsed adaptation and mitigations while others do not? Employing Protection Motivation Theory (PMT), this study delves into the socio-behavioral aspects such as feeling of vulnerability to climate change, perceived level of efficacy and coping appraisal of climate change adaptation and mitigation strategies. The central argument is that farmers need to perceive that climate change is occurring and affecting their livelihood in order to adopt mitigation and adaptation strategies.

\section{Protection Motivation Theory (PMT)}

The protection motivation theory (PMT) was first introduced by Rogers in 1975, in order to understand individual's response to potential threats of health problem. Later Rogers (1975) extended its iteration to other social science issues including environmental concern (Bagagnan, Ouedraogo, Fonta \& Sowe, 2019). The theory proposes a conceptual framework to explain factors predicting risk preventative behaviors. The central notion is that individuals' decision to participate in risk preventive behaviors is made based on their motivation to protect themselves from threats such as natural disasters and global climate change (Janmaimool, 2017) and people balance different risks and potential benefits (Keshavarz \& Karami, 2016). The decision of an individual towards risk preventive behavior is made based on the results of both threat appraisal and coping appraisal (Rogers, 1983).

Threat appraisal is a cognitive process that individuals use to estimate the level of threat (Janmaimool, 2017). It is directed to answering the question: is the existing risk (so) 
threatening? It includes two important elements: assessment of the perceived severity of the threat and the perceived probability of receiving adverse impacts from the threat (vulnerability). Accordingly, perceived severity of the threat means the degree of seriousness of the possible harms that is perceived by an individual while perceived vulnerability reflects an individual's perceptions of his susceptibility to the harms. These perceptions of vulnerability and severity motivate individuals to perform adaptive responses, such as climate change response measures (Janmaimool 2017). According to this theory, higher perception of severity and vulnerability is likely to enhance individual motivation to perform risk preventative behavior (Keshavarz \& Karami, 2016).

In addition to threat appraisal, coping appraisal, which refers to the estimation of an individual's capacity to perform risk preventative behaviors, also influences the protection motivation. At this stage, the key question is: Will my action help avoid or decrease the threat? (Osberghaus et al., 2010). The coping appraisal includes self-efficacy and response efficacy. Self-efficacy is an individual's perception of his ability to perform the behaviors. Response efficacy refers to the perceived effectiveness of the recommended risk preventative behaviors: will engaging in protective action actually reduce the risks? (Bockarjova \& Steg, 2014). Coping appraisal also considers the response cost, which is the cost of performing the recommended behavior (Rogers, 1983). A high cost of performing preventative behaviors might hinder people from being involved in recommended behaviors (Ihemezie, Onunka, \& Nnaji, 2018). The coping appraisal is the product of the appraisals of the self-efficacy and the response efficacy minus the costs of performing the recommended preventive the higher the response efficacy, self-efficacy. The lower response cost, the more possible one will decide to perform adaptive behaviors (Ihemezie et al., 2018; Janmaimool, 2017). So, in sum, people engage in climate change adaptation when confronted with (environmental) risks through perceived risk vulnerability and severity on the one hand, and by considering the possibilities to manage these risks through response efficacy and self-efficacy on the other hand (Bockarjova \& Steg, 2014).

\section{Methods}

\section{Description of the Study Area}

This study was conducted in Konta District, Ethiopia. Konta Special District is one of the fourteen zones and four special Districts in the South Nations Nationalities and Peoples Region (SNNPR) of Ethiopia. The study area is located between $6^{\circ}, 46^{\prime}-7$ ', 27' ' North latitude and $36^{\circ}, 32^{\prime}-36^{\prime}, 87^{\prime}$ ' East longitude, and South Western part of Ethiopia. It shares a boundary with Oromia Region in the North, Kaffa zone in the West, Dawro zone in the East, South Omo zone in the South and Gamo-Gofa zone in the Southeast. According to Central Statistics Agency (CSA, 2013) population projection, the total population of Konta special District in 2017 was 115,898 , of which 56,656 were male and 59,242 were female. Of the total population 98,314 $(84.8 \%)$ were rural. The district has 4 towns and 42 rural kebeles ${ }^{1}$. Mixed agriculture (crop production and animal husbandry) is the major livelihood activity and while off-farm sources of income including petty trading, daily labor, and handcrafts were supplementary livelihood activities practiced in the area (KDFED 2016). Regarding topographic feature, while $65 \%$ of the total land area is mountainous, $15 \%$ is undulating and the rest $20 \%$ is plain. Agroecologically, Konta Special District is classified in to wet Kolla (low altitude), Weyna Dega (mid-altitude) and Dega (high altitude) which accounts for 40\%, 54\% and 6\% of the total area respectively. Data from Konta Special District Early Warning and Food security Department

\footnotetext{
${ }^{1}$ the lowest administrative unit in Ethiopia
} 
shows that the average annual rainfall and temperature of Konta Special District in 2017 was $1583 \mathrm{~mm}$ and $20^{\circ} \mathrm{C}$ respectively. This figure was reported to show tremendous change as compared to measurement in the year 2009 where the annual rainfall was $1749 \mathrm{~mm}$ and temperature was recorded to be $18.95^{\circ} \mathrm{C}$. Annual rainfall decreased while the temperature was significantly raised.

\section{Research Design}

This study draws on mixed research approach in order to integrate qualitative data that emerge from subjective perception of farmers about climate change to quantitative information regarding the livelihood activities, perceived vulnerability and practices of adaptation strategies. Quantitative and qualitative data were collected concurrently. Issues, which were not adequately addressed in survey, were taken to qualitative method in order to gather rich data. Survey method was used to generate data about socio-demographic information, livelihood activities and practices of climate change adaptation and mitigation mechanisms. Data regarding subjective understanding about occurrence of climate change, perceived severity, vulnerability to climate change and challenges in practicing CRGE strategies were elicited using qualitative methods such as interviews, focus group discussions (FGDs) and key informant interviews. In order to examine farmers' practice of climate change adaptation and mitigation strategies, the study used cross-sectional study design. To this end, the purpose of this study was to ascertain threat and coping appraisal among farmers in Konta District in 2018.

\section{Sampling and data collection methods}

Since we could not find a compiled document consisting of all farmers in the District, multistage cluster sampling was employed to select the sample. Multi stage cluster sampling is used when there is no list of population. Since livelihood activities and strategies adopted to respond climate change are agro-ecologically sensitive in Ethiopia, agro-ecological condition was used to stratify kebeles. Hence, 42 rural kebeles in the District were classified into three based on agro-ecological conditions. In the first stage, three kebeles namely, Cheka Bocha, Mareka Godi and Konta Koysha were selected from each cluster (agro-ecology) through lottery method. The total farming household of the three kebeles was 1219. Next, sample was drawn for the total households of the three kebeles selected. In determining the sample size, Yamane (1967) formula was employed. Accordingly, the sample size was determined to be 301. Finally, the sample was administered proportionate to the size of each kebele. Purposive sampling was used to select participants for the Focus Group Discussions (FGDs) and key informant interviews (KII).

Survey, FGDs, in-depth interview and key informant were the main methods of data collection used in this study. Structured and semi-structured questionnaire were administered by the researchers to 301 farmers. The response rate was $98.3 \%$. This was mainly due to nonresponse rate and incomplete information from the selected sample. Three FGDs were conducted with women and men separately (one FGD in each sampled kebele). The main aim of FGD was to trace beliefs about climate change, perceived impacts, severity and vulnerability among the farmers. On average, FGDs took one and half an hour. The average number of participants was eight. Participants were recruited purposively based on their availability and willingness to join the discussion. Key informants participating in this study, among others, were Rural Development and Environmental Protection experts, agricultural extensions, elders and kebele chairpersons. They were interviewed regarding causes and consequences of climate change impacts, trends in climate change, government interventions and the practice of climate change adaptation and mitigation strategies. In-depth interview was used to gather household specific information about perceived severity, vulnerability, threat and coping appraisals they 
have employed in order to reduce the effect of climate change. Survey tool was pretested before actual data collection to check the consistency and logical flow as well as connections among the questions.

\section{Method of data analysis}

Quantitative data gathered from the sample households were analyzed by using both descriptive and inferential statistics. Descriptive statistics used in this study involves frequency, percentage, mean, standard deviation, crosstabs and Chi-square, while qualitative data was analyzed using thematic and content analysis. Themes regarding threat and coping appraisal were developed from Protection Motivation Theory (PMT) and data collected were categorized into components such as perceived severity, vulnerability, self-efficacy, response efficacy and perceived cost of practicing strategies recommended under CRGE. Yet, issues emerged in the field were analyzed through thematic analysis by developing themes from the data. Statistical Package for Social Science (SPSS) software version 20.0 was used to organize, code, clear and analyze quantitative data collected through survey. Binary logistic regression was employed to identify PMT and related variables that influence climate change and adaptation strategies. Before running binary logistic regression model, "base category or 'reference category' against which the odd ratio of practicing CRGE strategies is compared was defined. Accordingly, "not practiced" (not practicing certain climate change adaptation and mitigation strategy) was used as the base category. Therefore, the odd ratio, due to independent PMT variables, of practicing climate change adaptation and mitigation strategies was compared with 'not practicing' category. Moreover, Spearmen rho correlation was computed to check multicolinearity between explanatory variables. The association between each independent variable was found tolerable, which ranges from -0.002 to 0.361 .

\section{Results and Discussions}

\section{Demographic and Socio-Economic Characteristics of Respondents}

This study involved $87.2 \%$ male and $12.8 \%$ female survey respondents. The average age of respondents was 41. Majority of the respondents (89.9\%) were married, while $6.1 \%$ were widowed, divorced and never married category constitute $2 \%$ each respectively. Regarding education status, $42.2 \%$ of the household heads did not attend any kind of formal education. Only $7.8 \%$ of the respondents stated that they can only read and write. Some $36.55 \%$ of the respondents had completed primary education. Those who had completed secondary education constitute $11 \% ; 2.4 \%$ of the total sample had attended more above secondary education.

All the respondents were found to pursue mixed agriculture (crop production and animal husbandry); while handcraft as a means of livelihood was operated by only $5.5 \%$ and petty trading performed by $4.4 \%$. Table 1 shows that $3 \%$ of the respondents make their living from off-farm daily labor in agriculture. Limited possibility of livelihood diversification was reported in the study area. Diversification, if any, was found within agriculture. Multiple response output portrays that $99.3 \%$ of the respondents cultivate annual crop; while $94.3 \%$ grew perennial crop $91.6 \%$ of the respondents reported that they pursue animal husbandry. District Rural Development annual report and qualitative data generated from FGD revealed that teff, maize, wheat, barley, bean, and potato were among the major annual crops cultivated in the study area. Perennial crops produced in the area involve but not limited to avocado, mango, banana, inset and cassava. Crops grown by irrigation were tomatoes, onion and cabbage. 
Table 1: Economic activities of the respondents

\begin{tabular}{ccc}
\hline Socio-Economic characteristics & N=296 & Percentage \\
\hline 1. Livelihood activities* & & \\
• Agriculture & 296 & 100 \\
• Petty trading & 13 & 4.4 \\
• Daily labor & 9 & 3 \\
• Handcraft & 17 & 5.7 \\
2. Agricultural activities* & & \\
• Annual crop & 291 & 99.3 \\
• Perennial crop & 279 & 94.3 \\
• Animal husbandry & 271 & 91.6 \\
3. Main Agricultural Practice & & \\
• Rain-fed agriculture & 200 & 67.6 \\
• Irrigation Agriculture & 2 & 0.7 \\
• Both rain fed and irrigation) & 94 & 31.8 \\
\hline
\end{tabular}

* signifies multiple responses

\section{Source: survey result, April 2018}

The finding revealed that respondents practice agricultural diversification than spreading their livelihood activities beyond agriculture. Rain-fed agriculture predominates in the study area with $67.6 \%$ of the respondents practicing agriculture, which entirely depend on annual rainfall; while the rest $31.8 \%$ of the respondents reported to practice both irrigation and rain-fed agriculture. Indeed, this finding is not unique to the study area. In Ethiopia, agriculture is typically rain-fed. Limited diversification across sectors (e.g. between farm and non-farm sector) and dependence on single factor, climatic vagary, put farmers in countries like Ethiopia at risk of climate change effect (Berhe et al., 2017). Environmental protection experts pointed out that over dependence on annual rainfall pattern ended up in simultaneous shattering of all livelihood activities practiced by farmers in recent years due to hitherto unknown but intensifying trends of climate change.

\section{Perceptions of farmers about occurrence of Climate Change}

Responding to perceived threat is contingent up on subjective understanding of its occurrence and an assessment of the perceived potential consequence on one's own wellbeing. In this study, perception about climate change and its consequences were examined before ascertaining the climate change adaptation and mitigation practices among farmers. Result presented in table 2 shows that most $(97.6 \%)$ of the respondents recognized the happening of climate change in their vicinity. Some $69 \%$ of the respondents rated the change in climate as significant.

Table 2: Perceptions of farmers on the occurrence and trends of climate change

\begin{tabular}{llccc}
\hline & \multicolumn{1}{c}{ Items } & Response & N=296 & Percent \\
\hline $\mathbf{1}$ & Do you think the climate is changing in your & Yes & 289 & 97.6 \\
& locality? & No & 7 & 2.4 \\
$\mathbf{2}$ & How do you rate the extent of climate change & I don't know & 7 & 2.4 \\
& over the last ten years in the area? & Little change & 90 & 30.4 \\
& Significant change & 199 & 68.9 \\
\hline
\end{tabular}

\section{Source: survey, April 2018}

Concurrently, FGD participants unanimously claimed the tremendous change in climate 
situation over the last decades. Participants' enunciated that climate change was not a recent phenomenon in their area. New, according to participants, was accelerating change over the last decade than ever. Elders acknowledged the intergenerational climate variability and its increasing scale overtime. Participants enumerated different indicators, which they believe represent climate change in their area. An elder expressed the change in climate saying, "We are witnessing green desert". Regardless of the presumed better vegetation cover, according to district experts, temperature was reported to increase at an alarming rate.

\section{Perceived indicators and impacts of climate change}

Increasing non-seasonal and unpredictable rainfall pattern, increase in temperature, significant change in climatic zone and subsequent distortion in calendar of agricultural activities were among the main representations of climate change for the farmers in this study. Result presented in table 3 indicates that most of the respondents $(97 \%)$ witnessed that change in climate terms of erratic rainfall distribution; while $96.3 \%$ of the respondents identified climate change with the increasing temperature.

Table 3: Perceived indicators and threats of Climate Change Manifestations

\begin{tabular}{|c|c|c|c|}
\hline \multicolumn{4}{|c|}{ Perceive indicators } \\
\hline Indicators* & Response & Frequency & Percent \\
\hline \multirow[t]{2}{*}{ Erratic Distribution of rainfall } & Yes & 287 & 97 \\
\hline & No & 9 & 3 \\
\hline \multirow[t]{2}{*}{ Increasing of temperature } & Yes & 285 & 96.3 \\
\hline & No & 11 & 3.7 \\
\hline \multirow{2}{*}{$\begin{array}{l}\text { Change in climate zone and consequent agricultural } \\
\text { activities }\end{array}$} & Yes & 245 & 82.8 \\
\hline & No & 51 & 17.2 \\
\hline \multicolumn{4}{|c|}{ Perceived impacts of climate change } \\
\hline Perceived impacts* & Response & Frequency & Percent \\
\hline \multirow[t]{2}{*}{ Increased flood and landslide } & Yes & 245 & 82.8 \\
\hline & No & 51 & 17.2 \\
\hline \multirow[t]{2}{*}{ Drying of streams and river } & Yes & 228 & 77 \\
\hline & No & 68 & 23 \\
\hline \multirow[t]{2}{*}{ The occurrence of new disease and pests } & Yes & 284 & 95.9 \\
\hline & No & 12 & 4.1 \\
\hline \multirow[t]{2}{*}{ Recurrent drought } & Yes & 170 & 57.4 \\
\hline & No & 126 & 43.6 \\
\hline
\end{tabular}

* signifies multiple responses

\section{Source: Survey, April 2018}

Some $82.8 \%$ of the respondents attributed the change in climatic zone and consequent distortion in agricultural activities to change in climate. The following quote echoed this. Climate is changing at an alarming rate. Before some ten years, we were more or less certain about the seasonal characteristics. We used to know what would happen during the autumn, the winter, summer and spring. This had been governing our resource allocation. However, nowadays, unexpected events are emerging and thus we are not certain about seasons. Change in climate vagary has affected the cropping calendar and labor allocation. We are heavily dependent on climate. Change in climate change is causing hitherto unknown shocks to our livelihood. We are not certain (Male FGD participant, Age 47).

Agricultural extension workers also explained that climate change and subsequent distorted rainfall distribution had affected crop production calendar and resource allocation. FGD participants ascertained that distorted rainfall and uncertainty attached to seasonal vagaries not only affected their production pattern but also resulted in loss of resources such as 
labor and finance invested on inputs and farming activities. Examining meteorological data, Dang (2014) found that increased concentration of GHG has raised average temperature and altered the amount and distribution of rainfall, which is seriously affecting smallholder farming in developing countries. Among other factors, abnormal rainfall distribution was the most critical factor affecting the productivity of farmers who largely depend on rain fed agriculture (Alam et al., 2017). In addition to changes in rainfall and increasing temperature, FGD participants reported occurrence and ever-spreading scale of diseases such as malaria, maize fall armyworms and wheat rusts. Moreover, expansion of the ecological niche of annual crops such as teff, haricot bean and changes in closing style in the high-altitude were attributed to climate change during FGDs. According to district rural development expert, crops such as teff, that had been identified with only lowland agro ecology before some ten years, were reported to grow in mid-altitude and, though rarely, in highland areas too. Change in climate had resulted in alteration of climatic zones and crops cultivated in these zones. Similarly, according to FGD participants, malaria, which is previously a commonly known disease in lowland agro ecology, has become prevalent in middle altitude agro-ecology.

Increasing pattern and scale of flooding on the one hand and shortage of water, which often happens immediately following over flooding seasons on the other hand, were reported as a dilemma challenging the wellbeing of rural community according to district experts. Attributed to distorted rainfall pattern, it appears common to observe over flooding and drought within the same season according to key informants. Drying of water points and recurrent drought were mentioned as the main consequences of changing climate in the study area. Nonetheless, the effect of climate change was not uniform for all segments of population due to different roles they assumed in the community. Women FGD participants reported that decreasing surface water availability not only challenged crop production and livestock development but also it demanded more labor. This was reported to compromise labor which otherwise could be deployed to other livelihood tasks. Women informants further asserted that walking distance to water points was increasing than ever because streams closer to their homestead had already been dried. Amare \& Simane (2018) confirmed that rural people in Ethiopia are increasingly affected by climate change-induced hazards such as drought, flood, pests and disease, landslide, erratic and heavy rainfall that affects the environment and their livelihood.

\section{Threat Appraisal: Perceived severity of climate change risks and vulnerability}

The foregoing sections elaborated respondents' perception about climate change and the subsequent risks induced to their livelihood. This section discusses the threat appraisal, individual's assessment of the severity of a potential threat stimulus (climate change) and farmers perceived vulnerability to climate change, which comprises both the experienced and the expectation of being affected by the threat (climate change).

In this study, perceived severity grasps the perceived seriousness of problems arising from climate change. As partly illustrated in the discussion of perceived effects of climate change, respondents rated the seriousness of risks related to climate change to be very high. Majority of the respondents affirmatively reacted to a question "how serious the impact of climate change is to your life". As shown in table 4 below, $54.4 \%$ and $43 \%$ of the respondents rated the risk of climate change to be very serious and respectively serious to their wellbeing. Almost all respondents recognized that climate change poses serious threat to their life through affecting crop production and reducing household income. District environmental protection expert enunciated that farmers had been informed about the effect of climate change and thus had better understanding than it was in the past. The result of Likert scale further shows similar standard deviation across the statements measuring the perceived seriousness of the climate 
change threat. In other words, respondents' perception about the severity of climate change was similar among farmers in this study.

Table 4: Respondents perception on the severity of climate change effect Five-point Likert scale designates $1=$ Not Serious to 5=Very Serious

\begin{tabular}{|c|c|c|c|c|c|c|c|}
\hline \multirow[b]{2}{*}{ Statement } & \multicolumn{5}{|c|}{ \% Distribution } & \multirow{2}{*}{ Mean } & \multirow{2}{*}{ SD } \\
\hline & $\begin{array}{l}\text { Not } \\
\text { serious }\end{array}$ & $\begin{array}{l}\text { Less } \\
\text { serious }\end{array}$ & Undecided & Serious & $\begin{array}{l}\text { Very } \\
\text { serious }\end{array}$ & & \\
\hline $\begin{array}{l}\text { How you perceive the } \\
\text { severity of climate change } \\
\text { on the life of human } \\
\text { being? }\end{array}$ & 0 & 0.3 & 2 & 43.2 & 54.4 & 4.5 & 0.56 \\
\hline Impact on physical health & 0.5 & 4.4 & 7.1 & 55.1 & 32.8 & 4.1 & 0.78 \\
\hline Impact on income source & 0.7 & 2.7 & 4.7 & 51.4 & 29.7 & 4.3 & 0.73 \\
\hline $\begin{array}{l}\text { Physical asset (house, } \\
\text { land) }\end{array}$ & 1 & 1.4 & 5.7 & 54.7 & 37.2 & 4.3 & 0.71 \\
\hline $\begin{array}{l}\text { Impact on crop and animal } \\
\text { output and productivity }\end{array}$ & 1.4 & 1.7 & 3 & 44.3 & 49.7 & 4.4 & 0.75 \\
\hline $\begin{array}{l}\text { Impact on the happiness of } \\
\text { human life }\end{array}$ & 2 & 3.7 & 14.7 & 53.7 & 25.7 & 3.9 & 0.86 \\
\hline $\begin{array}{l}\text { Impact on making } \\
\text { property }\end{array}$ & 1.7 & 2 & 10.8 & 39.2 & 46.3 & 4.3 & 0.86 \\
\hline
\end{tabular}

Source: Survey, April 2018

Likert scale results were further corroborated by qualitative information.

We know climate change is not new. However, over the last decades Erratic rain and continuously increasing temperature in our locality have complicated the farming system more than ever. Almost all crops we have been growing become threated by different diseases hitherto unknown. Productivity has become more demanding. Survival had never been difficult as it is now. We are at risk! (Key informant, male, age, 43, Konta Koysha kebele).

The quote shows the increasing seriousness of climate change to the life of farmers by devastating resources, thereby production. As it is well illustrated, the more serious the climate change threat, the more demanding it is for farmers, in terms of resources, to produce and maintain their survival.

The second component of threat appraisal is perceived vulnerability. Perceived vulnerability captures the perceived susceptibility of an individual to the existing threat of climate change. The premises drawn from PMT is that the more farmers perceive they are vulnerable to climate change threats the more they adopt risk averting practices, either mitigation or adaptation in this study. To this end, the perceived susceptibility of farmers to climate change threat mentioned above was examined using Likert scale. Perceived vulnerability to climate change threat was rated across different points in time. The result depicted in table 5 shows that respondents rated their vulnerability to climate change to be very high. The mean scores of Likert scale $(\mathrm{M}=4.2, \mathrm{M}=4.3)$ illustrates that majority of the respondents perceived their life had been vulnerable to climate change threats and continued to be so. Higher mean was observed in the perceived vulnerability in the future. In other words, farmers feared that they would be vulnerable to climate change threats. 


\section{Table 5: Respondents perception on the vulnerability of farmers to climate change threat}

Five-point Likert scale designates $1=$ Not Vulnerable at al1 to 5=highly vulnerable

\begin{tabular}{lccc}
\hline Statement & Population & Mean & Standard Deviation \\
\hline My life was highly susceptible to climate change effect & 296 & 4.2 & 0.70 \\
I am highly being at risk of climate change & 296 & 4.3 & 0.62 \\
My livelihood will be exposed to climate change effect & 296 & 4.3 & 0.78 \\
\hline
\end{tabular}

Source: Survey, April 2018

Respondents rated their vulnerability to climate change threat to be high. According to agricultural extension workers and elders unless interventions are made to curb the situation, climate change will increase farmer's susceptibility. District Livestock Development experts explained farmers' vulnerability as follow: Farmers are trapped in spiral of vulnerabilities. Springs and rivers are drying. Water is in short supply. This means it is hard to keep cattle. This in turn means it is hard to cultivate crops. People are unable to produce and get adequate food. No adequate pasture for cattle. It used to rain mid-February. This year [in April], there is no rain. This is odd for us. People are relying only 'enset ${ }^{2}$ ' both for animal fodder and for themselves. Even this is possible only for those who have 'enset', those who do not have, have nothing to feed their cattle.

This excerpt shows that climate change poses vulnerabilities, which transcend particular season because the effects degrade the resource base of farmers who remain dependent on variable climate to make their livelihood. Kafula et al. (2017) also argued that farmers are particularly vulnerable to climate change because of their inherent dependence on natural resources for income and livelihoods and due to limited capacity to adapt to climate change.

\section{Practices of Climate Change Adaptation and Mitigation strategies}

This section deals with the reaction of the farmers towards the perceived threat of climate change risks. Adaptation and mitigation strategies enumerated in table 6 were derived from nationally initiated Climate Resilient Green Economy practiced since 2011. The initiative was based on the increasing vulnerability of Ethiopian economy regardless of its being the fastest growing economy in the world. Strategies were designed to avert the risk of climate change and maintain the agricultural sector, which remain the main source of national economy and living for the majority of the population. Strategies presented in table 6 were to be practiced by farmers on their farm and communal land. The finding shows that soil and water conservation (terracing, water harvesting and area closure among others) was the most widely practiced strategy pursued by $94.6 \%$ of respondents. On the other hand, fuel wood conservation (stove, solar panel and biogas) technologies, was found to be pursued by the smaller proportion of respondents (30.9\%). Moreover, respondents were observed to adopt practices such as reducing the expansion of agricultural land by increasing the scale of agricultural intensification (such as conservation agriculture, compost usage and increasing use of productivity enhancement technologies). Indeed, agricultural extension workers underscored the lesser possibility of extensification due to mounting population density. Almost all cultivable acreages were reported cultivated. About $84.8 \%$ of respondents reported to undertake agro-forestry like planting mango, avocado and apple fruits in addition to annual crops as principal mitigation

\footnotetext{
${ }^{2}$ A drought tolerant herbaceous species of flowering plant, often called Ethiopian banana, which is dominantly used for food in the Southern Nation, Nationalities and Peoples Region of Ethiopia.
} 
strategies.

Table 6: Respondents practices of climate change adaptation and mitigation strategies

\begin{tabular}{llccc}
\hline R. & Adaptation Strategies & Response & Frequency & Percent \\
\hline 1. & Increased use of small-scale irrigation (adaptation) & Practice & 96 & 32.4 \\
2. & $\begin{array}{l}\text { Changing the cropping calendar of agricultural } \\
\text { activities (adaptation) }\end{array}$ & Practice & 200 & 67.6 \\
& Do not practice & 146 & 49.3 \\
3. & $\begin{array}{l}\text { Adoption of drought tolerant and early maturing } \\
\text { crop varieties (adaptation) }\end{array}$ & Practice & 169 & 50.7 \\
& Do not practice & 127 & 47.1 \\
4. & $\begin{array}{l}\text { Diversification of off-farm (trade, daily labor, } \\
\text { migrate to urban) activities (adaptation) }\end{array}$ & Practice & 57 & 19.3 \\
& $\begin{array}{l}\text { Do not practice } \\
\text { 5. }\end{array}$ & 239 & 80.7 \\
& $\begin{array}{l}\text { (terracing, water harvesting, area closure) } \\
\text { technologies (adaptation) }\end{array}$ & Do not practice & 280 & 94.6 \\
& & & & 5.4
\end{tabular}

Mitigation Strategies

\section{Mitigation Strategies}

6. Reducing expansion of agricultural land through agricultural intensification (conservation agriculture, compost usage, using productivity enhancement technologies) (Mitigation)

7. Improving animal productivity through breeding (reducing number of local cattle population) (mitigation)

8 Diversification of small ruminant (sheep, goat, poultry) animals (mitigation)

9 Afforestation/ Reforestation (planting trees on communal and farm land) (mitigation)

10 Expansion of agro-forestry (mango, avocado, apple) development (mitigation)

11 Increased use of fuel wood conservation (stove, solar panel and bio-gas) technologies (mitigation)

12 Enhancing Participatory forest management (using forest products efficiently and expansion of economic activities in the forest) (mitigation)

\begin{tabular}{ccc}
\hline Response & Frequency & Percent \\
\hline Practice & 253 & 85.5 \\
Do not practice & 43 & 14.5 \\
& & \\
Practice & 112 & 37.8 \\
Do not practice & 184 & 62.2 \\
& & \\
Practice & 175 & 59 \\
Do not practice & 121 & 41 \\
Yes & 219 & 74 \\
Do not practice & 77 & 26 \\
Practice & 251 & 84.8 \\
Do not practice & 45 & 15.2 \\
Practice & 70 & 30.9 \\
Do not practice & 226 & 69.1 \\
Practice & 70 & 30.9 \\
Do not practice & 226 & 69.1 \\
& & \\
\hline
\end{tabular}

Source: Survey, April 2018

Table 6 further shows that almost three fourth of the respondents practiced afforestation/ reforestation (planting trees on communal and farmland); while 59\% practiced diversification of small ruminant animals. Almost all strategies presented in table 6 were practiced in three agro ecological conditions of the district. Diversification of off farm activities was relatively more practiced in the midland agro-ecological condition of the study area. According to agricultural extension workers and district rural development experts midland agro-ecology exhibits some features of lowland as well as highland climatic conditions. Consequently, activities which were assumed more practiced in highland agro-ecology such as diversification and those which were widely pursued in lowland were commonly practiced in the midland agro- 
ecology. While agricultural intensification was highly practiced in the highland and midland kebeles, expansion of agroforestry development was typical of lowland agro-ecology.

Even though majority of the respondents recognized the changes in climate and its impact on their livelihood as mentioned earlier, this study found that an average of $66.9 \%$ of the respondents practiced less than three adaptation strategies initiated by CRGE. On the other hand, the majority of farmers $(67.6 \%)$ practiced more than three mitigation strategies from the list. Nevertheless, the above result contradicts with the finding of Arbuckle et.al (2015) which stated that majority of farmers pursue adaptation strategies than activities to reduce GHG, mitigation. Respondents in this study were found to practice mitigation strategies more than adaptation. We are living in the mountainous area, which is not favorable for cultivation. We have been suffering from frequent erosion and landslide since the last decade. We cannot recover from devastation of climate change such as drought unless we take a care before it happened. To mitigate this, we are planting trees on the hillside, undertaking soil and water conservation structures on our farmland and inclosing hillsides for maintaining natural vegetation. We have been told by environmental experts that otherwise our life would be threatened (Male FGD participant, Age 42, Cheka Bocha Kebele).

Key informants also stated that mountainous and undulating nature of the study area presented a unique challenge to livelihood making activities. The study communities were known for planting of 'Enset', a drought tolerant plant which serves as both a food for humans and for animals. Enset was considered as crucial multipurpose crop that is used as adaptation mechanism among the people of Konta. In addition to this, cultivation of root crops including 'cassava' through intercropping not only supplemented the food production of the people but also relieved people from overdependence on annual rainfall, thereby reducing the effect of climate change.

\section{Coping appraisal: perceived self-efficacy, response efficacy and cost responding to climate change threats}

The second component of PMT is coping appraisal. Do farmers believe that their action will be able to reduce the threats of climate change? It is about farmer's assessment of his/her ability in responding to the perceived threat (i.e., impacts of climate change earlier). This involves assessment of farmer's own abilities to effectively carry out the adaptation behavior, whether the behavior under concern can in fact serve as a protective measure against threats posed by climate change and perceived costs of protective action. Table 7 shows the perceived self-efficacy of farmers measured on Likert scale. The grand mean of perceived self-efficacy was 3.42. The study found that farmers perceived they were more able to practice soil and water conservation more than other listed strategies. Relatively, perceived ability to practice irrigation as a response mechanism was found to be lower with a mean score of 2.5. Concerning mitigation strategies, perceived that they were able to adopt afforestation/reforestation and agro forestry using fuel wood conservation technologies. Key informants stressed that some climate change adaptation and mitigation strategies (such as solar energy and biogas) were beyond the local knowledge or expertise and thus demand more sensitization. 
Table 7: Respondents perception on self-efficacy of the response strategies

Five-point Likert scale in this table indicate $1=$ strongly unable to perform to $5=$ strongly able to perform

\begin{tabular}{|c|c|c|c|}
\hline \multicolumn{4}{|l|}{ Adaptation strategies } \\
\hline Perceived ability to effectively carry out & $\mathbf{N}$ & Mean & $\begin{array}{l}\text { Standard } \\
\text { Deviation }\end{array}$ \\
\hline Increased use of small-scale irrigation & 296 & 2.5 & 1.06 \\
\hline Changing cropping calendar of agricultural activities & 296 & 3.8 & 1.03 \\
\hline Adoption of drought tolerant and early maturing crop varieties & 296 & 3.7 & 0.91 \\
\hline $\begin{array}{l}\text { Diversification of off-farm (trade, daily labor, migrate to urban } \\
\text { activities) }\end{array}$ & 296 & 2.9 & 1.18 \\
\hline $\begin{array}{l}\text { Increased use of soil and water conservation (terracing, water } \\
\text { harvesting, area closure, and etc.) technologies }\end{array}$ & 296 & 4.0 & 0.59 \\
\hline \multicolumn{4}{|l|}{ Mitigation Strategies } \\
\hline Perceived ability to effectively carry out & $\mathbf{N}$ & Mean & $\begin{array}{l}\text { Standard } \\
\text { Deviation }\end{array}$ \\
\hline $\begin{array}{l}\text { Reducing expansion of agricultural land through agricultural } \\
\text { intensification (conservation agriculture, compost usage, using } \\
\text { productivity enhancement technologies) }\end{array}$ & 296 & 3.7 & 0.92 \\
\hline $\begin{array}{l}\text { Improving animal productivity through breeding (reducing number } \\
\text { of local cattle population) }\end{array}$ & 296 & 3.2 & 1.23 \\
\hline Diversification of small ruminant (sheep, goat, poultry) animals & 296 & 3.7 & 0.94 \\
\hline $\begin{array}{l}\text { Afforestation/ Reforestation (planting trees on communal and farm } \\
\text { land) }\end{array}$ & 296 & 3.8 & 0.98 \\
\hline Expansion of agro-forestry (mango, avocado, apple, development & 296 & 3.8 & 0.97 \\
\hline $\begin{array}{l}\text { Increased use of fuel wood conservation (stove, solar panel and bio- } \\
\text { gas) technologies }\end{array}$ & 296 & 2.8 & 1.37 \\
\hline $\begin{array}{l}\text { Enhancing Participatory forest management (using forest products } \\
\text { efficiently, and expansion of economic activities in the forest) }\end{array}$ & 296 & 3.1 & 1.37 \\
\hline Grand average & & 3.42 & 1.05 \\
\hline
\end{tabular}

Source: survey, April 2018

Agricultural intensification, as mentioned earlier was mentioned as a feasible strategy mainly due to limited land attributed to population pressure in the study area. FGD participants strengthen this fact. Not all activities you have mentioned are practiced uniformly among farmers. Some of us have large family size and thus labor to be deployed, for instance to soil and water conservation while others have not. Strategies such as irrigation require reliable access to water, labor, skill and finance.

\section{Do farmers believe that CRGE strategies they have been practicing are effective in reducing climate change risk?}

In addition to assessing the perceived ability of farmers in reacting to climate change threats, ascertaining the perceived effectiveness of the strategies is also vital in applying PMT. As depicted in table 8, majority of the CRGE strategies initiated by the government were perceived as effective in responding to climate change threats. More than 95 percent of the respondents perceived that soil and water conservation were the most effective strategies in reducing the risks of climate change followed by adoption of drought tolerant and early maturing crop varieties. FGD participants elaborated that the soil and water conservation scheme initiated by government (in 2011) was effective in reducing soil erosion, improving soil fertility, regenerating pasture and increasing water availability. Key informants also affirmed the relevance and effectiveness of adoption of drought tolerant and early maturing crop varieties in reducing climate change risks. The following quote from FGD participant elaborate this. 
Haricot bean, sesame and cassava had not been known as is it is now. After sensitization by the district rural development, currently these crops were adopted both as a means of getting supplementary income and as a strategy to reduce risks attached to climate change. I have been producing haricot bean for the last three years. It gives harvest within three months even when the rain is inadequate.

Table 8: Perceived Response Efficacy of Respondents

\begin{tabular}{|c|c|c|c|c|}
\hline R. & $\begin{array}{l}\text { Do you think the following strategies are } \\
\text { effective in reducing risks due to climate } \\
\text { change }\end{array}$ & Response & Frequency & Percent \\
\hline 1. & Increased use of small-scale irrigation & $\begin{array}{l}\text { Yes } \\
\text { No }\end{array}$ & $\begin{array}{c}215 \\
81\end{array}$ & $\begin{array}{l}72.6 \\
27.4\end{array}$ \\
\hline 2. & $\begin{array}{l}\text { Changing cropping calendar of agricultural } \\
\text { activities }\end{array}$ & $\begin{array}{l}\text { Yes } \\
\text { No }\end{array}$ & $\begin{array}{c}202 \\
93\end{array}$ & $\begin{array}{l}68.2 \\
31.4\end{array}$ \\
\hline 3. & $\begin{array}{l}\text { Adoption of drought tolerant and early maturing } \\
\text { crop varieties }\end{array}$ & $\begin{array}{l}\text { Yes } \\
\text { No }\end{array}$ & $\begin{array}{c}253 \\
43\end{array}$ & $\begin{array}{l}85.5 \\
14.5\end{array}$ \\
\hline 4. & $\begin{array}{l}\text { Diversification of off-farm (trade, daily labor, } \\
\text { migrate to urban) activities }\end{array}$ & $\begin{array}{l}\text { Yes } \\
\text { No }\end{array}$ & $\begin{array}{l}102 \\
194\end{array}$ & $\begin{array}{l}34.5 \\
65.5\end{array}$ \\
\hline 5. & $\begin{array}{l}\text { Increased use of soil and water conservation } \\
\text { (terracing, water harvesting, area closure) } \\
\text { technologies }\end{array}$ & $\begin{array}{l}\text { Yes } \\
\text { No }\end{array}$ & $\begin{array}{c}282 \\
60\end{array}$ & $\begin{array}{c}95.3 \\
4.7\end{array}$ \\
\hline & \multicolumn{4}{|c|}{ Mitigation strategies } \\
\hline & $\begin{array}{l}\text { Do you think the following strategies are effective } \\
\text { in mitigating climate change risks? }\end{array}$ & Response & Frequency & Percent \\
\hline 6. & $\begin{array}{l}\text { Reducing expansion of agricultural land through } \\
\text { agricultural intensification (conservation } \\
\text { agriculture, compost usage, using productivity } \\
\text { enhancement technologies) }\end{array}$ & $\begin{array}{l}\text { Yes } \\
\text { No }\end{array}$ & $\begin{array}{c}236 \\
60\end{array}$ & $\begin{array}{l}79.7 \\
20.3\end{array}$ \\
\hline 7. & $\begin{array}{l}\text { Improving animal productivity through breeding } \\
\text { (reducing number of local cattle population) }\end{array}$ & $\begin{array}{l}\text { Yes } \\
\text { No }\end{array}$ & $\begin{array}{l}194 \\
102\end{array}$ & $\begin{array}{l}65.5 \\
34.5\end{array}$ \\
\hline 8 & $\begin{array}{l}\text { Diversification of small ruminant (sheep, goat, } \\
\text { poultry) animals }\end{array}$ & $\begin{array}{l}\text { Yes } \\
\text { No }\end{array}$ & $\begin{array}{c}202 \\
95\end{array}$ & $\begin{array}{l}67.9 \\
32.9\end{array}$ \\
\hline 9 & $\begin{array}{l}\text { Afforestation/ Reforestation (planting trees on } \\
\text { communal and farm land) }\end{array}$ & $\begin{array}{l}\text { Yes } \\
\text { No }\end{array}$ & $\begin{array}{c}276 \\
20\end{array}$ & $\begin{array}{c}93.2 \\
6.8\end{array}$ \\
\hline 10 & $\begin{array}{l}\text { Expansion of agro-forestry (mango, avocado, } \\
\text { apple) development }\end{array}$ & $\begin{array}{l}\text { Yes } \\
\text { No }\end{array}$ & $\begin{array}{c}268 \\
28\end{array}$ & $\begin{array}{c}90.5 \\
9.5\end{array}$ \\
\hline 11 & $\begin{array}{l}\text { Increased use of fuel wood conservation (stove, } \\
\text { solar panel and bio-gas) technologies }\end{array}$ & $\begin{array}{l}\text { Yes } \\
\text { No }\end{array}$ & $\begin{array}{l}129 \\
167\end{array}$ & $\begin{array}{l}43.6 \\
56.4\end{array}$ \\
\hline 12 & $\begin{array}{l}\text { Enhancing Participatory forest management (using } \\
\text { forest products efficiently and expansion of } \\
\text { economic activities in the forest) }\end{array}$ & $\begin{array}{l}\text { Yes } \\
\text { No }\end{array}$ & $\begin{array}{c}217 \\
79\end{array}$ & $\begin{array}{l}73.3 \\
26.7\end{array}$ \\
\hline
\end{tabular}

\section{Source: Survey, April 2018}

Relatively smaller percentage observed in the diversification to off farm activities shows respondents reluctance about the feasibility of diversification as adaptation mechanism. This could be due to resource constraint discussed above. Regarding mitigation strategies, farmers' perceived afforestation/reforestation as the most effective strategy in reducing climate change induced risks. Compared to other mitigation strategies, fuel wood utilization was considered as less effective among respondents. Lack of resources and skills to run these practices were 
mentioned as the major challenges to adopt these practices. Overall, mitigation strategies were perceived to be more effective as compared to adaptation strategies enumerated in their study.

\section{How do farmers rate costs of adaptive and mitigation strategies?}

In addition to the perceived seriousness, vulnerability, perceived ability to practice responses and perceived effectiveness of the responses, PMT appraises the perceived cost of each strategy, which could affect individuals' motive to practice certain behavior against the perceived threat. In this study, the argument is that perceived cost of implementing the adaptation and mitigation strategies influences farmers' motive in pursuing adaptation and mitigation strategies. The affirmative responses were coded as 'not costly'. In other words, the larger value in the Likert scale means, respondents perceived the strategy under question as not costly. Eleven out of twelve strategies adopted from CRGE were perceived by the respondent as costly (or with Mean <3). Only changing cropping calendar was perceived as less costly to farmers involved in this study.

\section{Table 9: Respondents perception on cost of performing climate change response strategies}

(Five-point Likert scale in this table indicate $1=$ highly costly to $5=$ not costly at all)

\begin{tabular}{|c|c|c|c|c|}
\hline \multicolumn{5}{|c|}{ Adaptation strategies } \\
\hline \multirow{2}{*}{$\begin{array}{l}\text { To what extent you perceive the following adaptation } \\
\text { strategies are costly: }\end{array}$} & money & labor & time & \multirow{2}{*}{$\begin{array}{l}\text { Average } \\
\text { mean }\end{array}$} \\
\hline & mean & mean & mean & \\
\hline Increased use of small scale irrigation & 1.2 & 1.2 & 1.7 & 1.41 \\
\hline Changing cropping calendar of agricultural activities & 3.0 & 3.1 & 2.9 & 3.03 \\
\hline $\begin{array}{l}\text { Adoption of drought tolerant and early maturing crop } \\
\text { varieties }\end{array}$ & 2.5 & 1.7 & 1.9 & 2.00 \\
\hline $\begin{array}{l}\text { Diversification of off-farm (trade, daily labor, migrate to } \\
\text { urban) activities }\end{array}$ & 2.1 & 3.1 & 3.0 & 2.73 \\
\hline $\begin{array}{l}\text { Increased use of soil and water conservation (terracing, } \\
\text { water harvesting, area closure) technologies }\end{array}$ & 3.1 & 1.5 & 1.8 & 2.12 \\
\hline $\begin{array}{l}\text { Mitigation str } \\
\text { To what extent you perceive the following strategies } \\
\text { are costly: }\end{array}$ & egies & & & \\
\hline $\begin{array}{l}\text { Reducing expansion of agricultural land through } \\
\text { agricultural intensification (conservation agriculture, } \\
\text { compost usage, using productivity enhancement } \\
\text { technologies) }\end{array}$ & 1.5 & 1.7 & 2.0 & 1.74 \\
\hline $\begin{array}{l}\text { Improving animal productivity through breeding } \\
\text { (reducing number of local cattle population) }\end{array}$ & 2.3 & 3.5 & 2.2 & 2.68 \\
\hline $\begin{array}{l}\text { Diversification of small ruminant (sheep, goat, poultry) } \\
\text { animals }\end{array}$ & 1.7 & 3.4 & 2.3 & 2.48 \\
\hline $\begin{array}{l}\text { Afforestation/ Reforestation (planting trees on communal } \\
\text { and farm land) }\end{array}$ & 3.1 & 1.6 & 1.4 & 2.07 \\
\hline $\begin{array}{l}\text { Expansion of agro-forestry (mango, avocado, apple) } \\
\text { development }\end{array}$ & 3.0 & 1.7 & 1.5 & 2.08 \\
\hline $\begin{array}{l}\text { Increased use of fuel wood conservation (stove, solar } \\
\text { panel and bio-gas) technologies }\end{array}$ & 1.4 & 3.2 & 3.3 & 2.63 \\
\hline $\begin{array}{l}\text { Enhancing participatory forest management (using forest } \\
\text { products efficiently and expansion of economic activities } \\
\text { in the forest) }\end{array}$ & 2.9 & 2 & 1.7 & 2.22 \\
\hline
\end{tabular}

\section{Source: survey, April 2018}

Small-scale irrigation was perceived as highly costly $(\mathrm{M}=1.41, \mathrm{SD}=0.52)$ in terms of finance, labor and time, relative to other adaptation and mitigation strategies. Adoption of 
drought tolerant and early maturing crop varieties and agricultural intensification were ranked second and third in terms of the perceived cost required in terms of finance, labor and time. Key informants and FGD participants also noted that increasing cost of input such as fertilizer and improved seed varieties were demanding more resources, which were often in short supply and costly. Participants were found skeptical about the sustainability of improved varieties of crops due to the fluctuating climate.

\section{Determinants of Climate Change Adaptation}

This study tested the influence of variables derived from PMT (perceived severity, perceived vulnerability, perceived self-efficacy, perceived response efficacy, perceived cost of recommendation) on the adoption and practices of CRGE strategies. Binary logistic regression was employed in order to identify variables which predict the odd ratio of practicing certain adaptation and mitigation strategies as compared to 'not adopting the practice' which is coded as No' category. Table 9 shows the output of binary logistic regression computed for testing the PMT variables that determine each adaptation strategy derived from CRGE. The result shows that majority of the PMT variables predict the practice of small-scale irrigation, changing cropping calendar and Adoption of drought tolerant and early maturing crops whereas diversification of off-farm activities could only be predicted by perceived self-efficacy.

Table 11: Determinants of climate change adaptation strategies

\begin{tabular}{|c|c|c|c|c|c|c|c|c|c|c|c|c|c|c|c|}
\hline \multirow{4}{*}{ Determinants } & \multicolumn{15}{|c|}{ Adaptation strategies } \\
\hline & \multicolumn{3}{|c|}{ Model 1} & \multicolumn{3}{|c|}{ Model 2} & \multicolumn{3}{|c|}{ Model 3} & \multicolumn{3}{|l|}{ Model 4} & \multicolumn{3}{|c|}{ Model 5} \\
\hline & \multicolumn{3}{|c|}{ Small scale irrigation } & \multicolumn{3}{|c|}{ Changing cropping calendar } & \multicolumn{3}{|c|}{$\begin{array}{l}\text { Adoption of drought tolerant and } \\
\text { early maturing crops }\end{array}$} & \multicolumn{3}{|c|}{$\begin{array}{l}\text { Diversification of off-farm } \\
\text { activities }\end{array}$} & \multicolumn{3}{|c|}{$\begin{array}{c}\text { Soil and water conservation } \\
\text { measures }\end{array}$} \\
\hline & $\begin{array}{c}\text { Exp } \\
(B)\end{array}$ & S.E & $\begin{array}{l}\mathrm{p}- \\
\text { value }\end{array}$ & $\begin{array}{l}\text { Exp } \\
\text { (B) }\end{array}$ & S.E & p-value & $\begin{array}{l}\text { Exp } \\
\text { (B) }\end{array}$ & S.E & p-value & $\begin{array}{l}\text { Exp } \\
\text { (B) }\end{array}$ & S.E & $\begin{array}{l}\mathrm{p}- \\
\text { value }\end{array}$ & $\begin{array}{l}\text { Exp } \\
\text { (B) }\end{array}$ & S.E & $\begin{array}{l}\mathrm{p}- \\
\text { value }\end{array}$ \\
\hline Educational status & $\begin{array}{r}1.28 \\
5\end{array}$ & .321 & .434 & 2.147 & .288 & $.008 * *$ & 1.618 & .286 & .092 & 1.245 & .345 & .525 & 2.606 & .632 & .130 \\
\hline $\begin{array}{ll}\text { Access } & \text { to } \\
\text { information } & \end{array}$ & $\begin{array}{r}2.45 \\
2\end{array}$ & .513 & .081 & 0.833 & .386 & .635 & 2.076 & .368 & $.047 *$ & 1.366 & .463 & .501 & 6.181 & .675 & $\begin{array}{l}.007 * \\
*\end{array}$ \\
\hline $\begin{array}{l}\text { Belief in causes of } \\
\text { climate change }\end{array}$ & $\begin{array}{r}2.73 \\
8\end{array}$ & .316 & $.001^{*}$ & 2.385 & .285 & $.002 * *$ & 0.952 & .285 & .863 & 1.109 & .325 & .750 & 1.962 & .589 & .252 \\
\hline $\begin{array}{l}\text { Ecological value } \\
\text { of respondents }\end{array}$ & $\begin{array}{r}1.08 \\
7\end{array}$ & .281 & .767 & 3.258 & .255 & $.000 * *$ & 2.199 & .242 & $.001 * *$ & 1.287 & .301 & .402 & 0.335 & .499 & $.028 *$ \\
\hline Perceived severity & $\begin{array}{r}2.50 \\
4\end{array}$ & .392 & $\begin{array}{r}.019 \\
*\end{array}$ & 1.488 & .312 & .208 & 1.614 & .303 & .114 & .585 & .355 & .131 & 1.851 & .597 & .302 \\
\hline $\begin{array}{l}\text { Perceived } \\
\text { vulnerability }\end{array}$ & $\begin{array}{r}3.71 \\
1\end{array}$ & .439 & $\begin{aligned} .003 \\
* *\end{aligned}$ & 1.906 & .328 & $.049 *$ & 1.957 & .319 & $.036^{*}$ & .840 & .362 & .630 & 0.583 & .675 & .425 \\
\hline Self-efficacy & $\begin{array}{r}1.24 \\
8\end{array}$ & .321 & .489 & 1.781 & .287 & .389 & 2.177 & .277 & $.005 * *$ & 2.359 & .344 & .012 & 0.715 & .607 & .580 \\
\hline Response efficacy & $\begin{array}{r}1.47 \\
3\end{array}$ & .419 & .355 & 2.060 & .354 & $.041 *$ & 1.362 & .338 & .360 & .941 & .393 & .877 & 0.485 & .771 & .348 \\
\hline Response cost & $\begin{array}{r}4.39 \\
0\end{array}$ & .341 & $\begin{aligned} .000 \\
* *\end{aligned}$ & 2.177 & .333 & $.020 *$ & 3.388 & .375 & $.001 * *$ & .579 & .408 & .180 & 0.386 & .660 & .149 \\
\hline
\end{tabular}

$*, * *$ significant at $5 \%$ and $1 \%$ respectively

Likelihood test for small-scale irrigation was found significant. Belief in causes of climate change, perceived vulnerability and perceived cost of recommendation were found to significantly determine the practice of small-scale irrigation. Keeping other variables constant, believing in climate change as anthropogenic or human induced increased the odd ratio of practicing irrigation by a factor of two as compared to attributing cause of climate change to natural factor. The influence was significant at $\mathrm{p}<0.05$. Similarly, those who perceived that 
climate change threat was severe practiced small-scale irrigation 2 times more than those who did not consider climate change as severe. Changing cropping calendar was also significantly predicted by six variables included in the model. Educated farmers were also found to practice changing cropping calendar as compared to the uneducated farmers. The result was significant at $1 \%$. Belief in causes of climate change predicted the odd ratio of practicing cropping calendar at $1 \%$ probability level and by a factor of two as compared to not practicing. Perceived vulnerability, perceived response efficacy and perceived cost of recommendation significantly predicted the practice of changing cropping calendar 5\%. Those who consider cropping calendar as less costly practice changing cropping calendar two times more than those who perceive it as costly.

Adopting drought tolerant and early maturing crop varieties was predicted by access to information about climate change, ecological value of the respondent, perceived vulnerability, self-efficacy and perceived cost undertaking the recommended cost. Keeping other variables constant, those who perceived they are able to respond to climate change threat adopted drought tolerant crops two times more than those who perceived that they were unable to respond. Selfefficacy and perceived cost of recommendation significantly predicted adoption of tolerant and early maturing crop varieties at $1 \%$, while perceived vulnerability was significant at $5 \%$. Diversification of off-farm activities as an adaptation strategy was predicted by only perceived self-efficacy at $5 \%$ probability level. Soil and water conservation was predicted by access to information and ecological value of the respondents. In other words, respondents who were found to give higher priority to ecosystem protection were found to practice soil and water conservation than those who give lower attention.

\section{Determinants of Climate Change mitigation}

Table 12 shows that five factors were found to significantly predict the likelihood of practicing agricultural intensification as a mitigation strategy. Controlling all other variables, having access to climate change information, having favorable attitude to environmental protection, perceived susceptibility and considering cost of recommendation as less costly were found to predict the likelihood of practicing agricultural intensification. Respondents who perceived that they were vulnerable to climate change were found to practice agricultural intensification more than those who perceived their situation as less vulnerable. The result was significant at $5 \%(\mathrm{p}=0.041)$. Relatedly, those who perceived agricultural intensification were found to practice it 4 times than those who received the practice as costly. Access to information, as presented in table 12, predicted the practice of agricultural intensification more strongly than other variables $(\mathrm{p}=0.000$ or significant at $1 \%)$. Self-efficacy and perceived response efficacy of the respondents predicted the adoption of improved animal breeding at $5 \%$ $(\mathrm{P}=0.049)$ and $(\mathrm{p}=0.026)$ respectively. In other words, those responds who perceived they were able to adopt improved animal breeding and considered it as effective in mitigating climate change threat were more likely to practice that than those who perceived they were unable to practice and considered adoption of animal breeding as less effective. As compared to those who attribute climate change to natural phenomenon or wrath of God household heads who perceive climate change is human induced problem were 2.047 times more likely to practice improving animal productivity.

Of the PMT variables, self-efficacy and perceived cost of practice were found to predict diversification of small ruminant at 5\%. Afforestation/reforestation strategy was significantly predicted by educational status, belief in anthropogenic factors as a cause of climate change, perceiving climate change as severe, perceived self-efficacy and response efficacy at $5 \%$. Those who perceived afforestation as less costly were found to practice it two times more than those who consider afforestation as more costly. The binary logistic regression further indicates that 
educated farmers were six times more likely to practice agroforestry development (planting perennial crops such as mango, avocado) than the uneducated. Those who considered adoption of fuel wood conservation technologies (such as solar energy) as less costly were found to practice it 2.6 more times than those who consider it as costly and the result was significant at $1 \%$. 
Table 12: Results of binary logistic regression models indicating determinants of climate change Mitigation strategies

\begin{tabular}{|c|c|c|c|c|c|c|c|c|c|c|c|}
\hline \multirow[b]{3}{*}{ 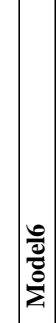 } & \multirow{3}{*}{ 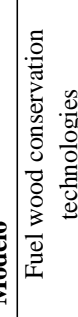 } & $\dot{2}$ & 8. & $\stackrel{\infty}{8}$. & $\begin{array}{l}\text { 离 } \\
\text { in }\end{array}$ & fి & 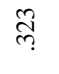 & ते & 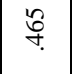 & $\frac{\partial}{7}$ & $\tilde{\delta}$ \\
\hline & & بr. & $\hat{m}$ & $\hat{b}$ & $\vec{m}$ & क्ष̣ & भ̊ & $\underset{\overbrace{}}{\stackrel{+}{\sharp}}$ & $\tilde{f}$ & స్ర & సે \\
\hline & & खे & 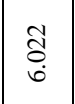 & $\begin{array}{l}\ddot{2} \\
\stackrel{\leftrightarrow}{\circ}\end{array}$ & 志 & & $\tilde{b}$ & 号 & 察 & . & 占 \\
\hline \multirow[b]{3}{*}{ 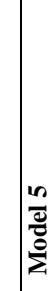 } & \multirow{3}{*}{ 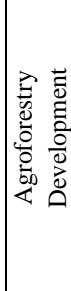 } & $\dot{2}$ & 8. & 卓 & $\overline{8}$ & ㅇ. & ڤ్ & $\stackrel{\infty}{\circ}$ & สิ & f. * & ๙े \\
\hline & & w & f. & 导 & $\overline{\mathrm{g}}$ & ले & ‡. & సે & 导 & 号 & $\stackrel{m}{q}$ \\
\hline & & 畜 $\widehat{\theta}$ & 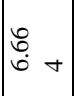 & $\stackrel{\partial}{-}$ & 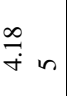 & 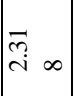 & $\overline{\sigma o g}$. & $\tilde{\sigma} \sigma$ & 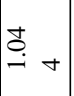 & ît & ర్లై \\
\hline \multirow{3}{*}{ 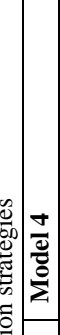 } & \multirow{3}{*}{ 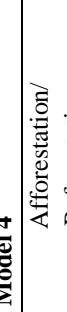 } & 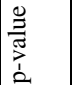 & $\stackrel{*}{*}$ & $\stackrel{\sim}{m}$ & $\hat{\partial}$ & $\hat{\imath}$ & 尊 & $\widehat{\overbrace{}}$ & 。 & 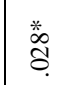 & $\frac{\infty}{\sigma}$ \\
\hline & & & సે & 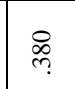 & $\frac{\circ}{m}$ & స్రి & $\frac{\infty}{m}$ & ల్లి & f & ळે & ff \\
\hline & & 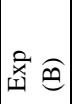 & స్తి & 尔 & बे & $\stackrel{\vec{a}}{\dot{S}}$ & 㕝 & 守 & 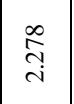 & : & ֻْ \\
\hline & \multirow{3}{*}{ 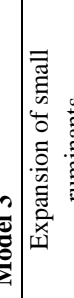 } & L & స્తి & छి. & f8 & $\frac{n}{m}$ & 웡 & है & $\stackrel{\infty}{8}$ & $\begin{array}{l}\infty \\
\stackrel{2}{?}\end{array}$ & $\overline{\widehat{\sigma}}$. * \\
\hline & & 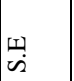 & هి & $\stackrel{\circ}{7}$ & $\overrightarrow{\stackrel{\infty}{\oplus}}$ & 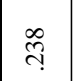 & $\frac{n}{m}$ & $\stackrel{\infty}{m}$ & ल్లి & $\stackrel{\infty}{+}$ & 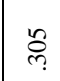 \\
\hline & & 圭 $\widehat{\theta}$ & $\stackrel{n}{g}$ & 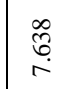 & 答 & 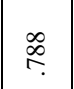 & 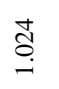 & 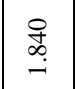 & $\frac{\partial}{\vec{\gamma}}$ & $\stackrel{Ð}{\rightleftarrows}$ & $\begin{array}{l}\overrightarrow{\widehat{D}} \\
\text { i }\end{array}$ \\
\hline \multirow{3}{*}{ 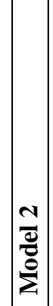 } & \multirow{3}{*}{ 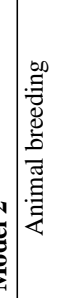 } & $\dot{2}$ & ڤ్ণ & $\stackrel{9}{\circ}$ & 8े & $\fallingdotseq$ & 导 & 夺 & go & జ & 今̊ \\
\hline & & w & 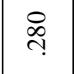 & 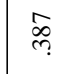 & 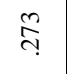 & 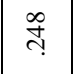 & $\frac{n}{m}$ & లె & $\overrightarrow{\tilde{\sigma}}$ & $\stackrel{\vec{\delta}}{\stackrel{s}{f}}$ & $\stackrel{+}{\stackrel{+}{\oplus}}$ \\
\hline & & 畜 $\widehat{\theta}$ & 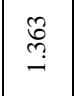 & $\stackrel{\varrho}{\leftrightarrows}$ & $\begin{array}{l}\text { fo } \\
\text { i }\end{array}$ & 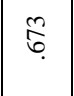 & $\stackrel{n}{\stackrel{n}{s}}$ & 怘 & $\begin{array}{l}\text { } \\
\stackrel{\text { Oे }}{i}\end{array}$ & $\frac{ \pm}{9}$ & $\stackrel{\infty}{\stackrel{\infty}{-}}$ \\
\hline \multirow{3}{*}{$\mid \begin{array}{l}\bar{z} \\
\overline{\bar{z}} \\
\overline{\bar{z}} \\
\bar{z}\end{array}$} & \multirow{3}{*}{ 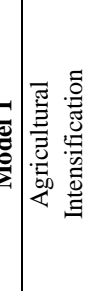 } & 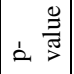 & वे & 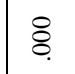 & 厄... & है. & $\stackrel{n}{\stackrel{n}{r}}$ & $\bar{\theta}_{*}$ & ત્ণి & 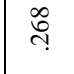 & $\overline{\bar{\sigma}}_{*}$ \\
\hline & & 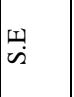 & ఫे & 年 & 草 & లో & ซ్ & 辇 & 守 & 㤐 & 它 \\
\hline & & 훕 & $\stackrel{m}{\stackrel{2}{I}}$ & 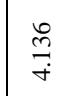 & ֶָ. & \begin{tabular}{l}
$n$ \\
\multirow{b}{0}{} \\
i
\end{tabular} & $\underset{\infty}{ \pm}$ & के & 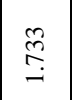 & 悹 & $\begin{array}{l}\frac{1}{0} \\
\dot{+}\end{array}$ \\
\hline \multicolumn{3}{|l|}{ 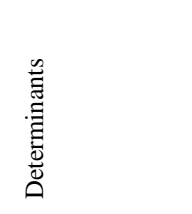 } & 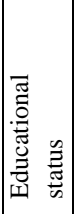 & 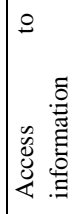 & 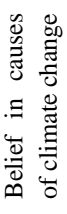 & 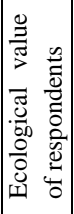 & & 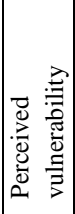 & 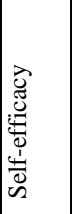 & 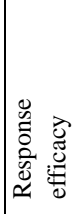 & 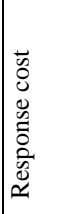 \\
\hline
\end{tabular}

$*$, ** significant at $5 \%$ and $1 \%$ respectively 


\section{Discussion}

Climate change is widely acknowledged as a major threat facing the world today and predicted to challenge wellbeing in the future. In countries like Ethiopia where majority of the population derive their livelihood from rain-fed agriculture, the effect of climate change is more serious. This necessitated the designation and adoption across the world of measures to combat climate change threats. The two, often complementing strategies sensitized by Intergovernmental Panel on Climate Change are mitigation and adaptation strategies (Osberghaus et al., 2010). This study tested the application of PMT in identifying climate change adaptation and mitigation strategies. The basic assumption was that behavioral change of the rural people is important for practicing climate change adaptation and mitigation strategies. The central argument is that farmers pursued adaptive strategies when they believed they confronted with (environmental) risks through perceived risk vulnerability and severity on the one hand, and by considering the possibilities to manage these risks through response efficacy and self-efficacy on the other hand (Bockarjova \& Steg, 2014). Climate change adaptation and mitigations involve a two-step process. First, farmers must perceive that climate change is occurring and threatening their wellbeing. This is followed by adopting certain practices, considered feasible to their context, in order to avert the threat believed to be induced by the change in climatic vagary (Asrat \& Simane, 2018b).

Almost all respondents under this investigation recognized that climate change was occurring. Climate change was perceived as the main threat among the farmers studied. Farmers illustrated the change in climatic vagaries in terms of increasing temperature, distorted and nonseasonal rain and change in climatic zones. Feleke et al. (2016) also confirmed that majority of the farmers in Northern Ethiopia perceived that climate change is indeed occurring and mentioned changes in temperature and precipitation as the main parameters. From their farming experience, farmers understood not only the change in climatic situation but also judge its extent of change over time to be serious to their existence (Alam et al., 2017; Asrat \& Simane, 2018). Climate change is represented as change in rainfall distribution, increasing temperature, water scarcity and dwindling productivity overtime (Limantol et al., 2016). Study farmers added the manifestation of disease and shifting of different plant and human disease across climatic zones over the recent years.

People undertake adaptive actions when confronted with (environmental) risks through perceived risk vulnerability and severity on the one hand and by considering the possibilities to manage these risks through response efficacy and self-efficacy on the other hand (Bockarjova $\&$ Steg, 2014). Threat appraisal is very important in order to react to the perceived threat. The more farmers consider climate change as a threat to their wellbeing the more they react to climate change risks. Respondents in this study underscored that climate change is accelerating in the community. Thus, the perceived severity of farmers to climate change threats such as flooding, shortage of precipitation and ultimately recurrent drought was reported to be higher than ever (Deressa, 2008). This is not unique to the study population because smallholder farming system is highly vulnerable to changing climatic situation (Ali \& Erenstein, 2017).

Mitigation and adaptation strategies are often complementary mechanisms to reduce the threat of climate change. Mitigation is a measure that takes place at the global scale, whereas adaptation can occur at various levels, from local to global (Osberghaus et al., 2010). Farmers recognized the adverse effect of climate change on income, wellbeing and productivity. Farmers show a higher adaptation intention when they perceive higher climate risks threatening their physical health, finances, production, social relationships and psychology (Luu, Nguyen, Trinh, Pham, \& Le, 2019). Perception about the occurrence of climate change does not necessarily leads to adopting and practicing mitigation strategies. Farmers in the study are practiced adaptation strategies suggested by Climate Resilient Green Economy recommended by the 
government though there is no uniform distribution among respondents. Soil and water conservation were found to be the most widely practiced adaptation strategy in the study area while the potential of practicing irrigation was limited due to resource. Soil and water conservation have been initiated by the government practiced by farmers for the last ten years. In North Western Ethiopia, Asrat \& Simane (2018) also found soil and water conservation and agronomic practices such as crop rotation, intercropping, adjusting planting dates as the widely practiced adaptation strategies.

Perceived severity of climate change and consequent drought significantly encouraged farmers to continue conserving soil and water (Keshavarz \& Karami, 2016). Not all adaptation and mitigation strategies derived from CRGE were perceived feasible by the farmers. Another component of coping appraisal is perceived susceptibility. Farmers who believed that they were highly vulnerable to climate change practiced strategies such as changing cropping calendar, small scale irrigation and adoption of drought tolerant and early maturing crops. A comparative investigation among East African countries: Ethiopia, Kenya, Uganda and Tanzania revealed that poor resilience farming system continue to put farmers at risk of climate change in the region (Shikuku et al., 2017). The perceived higher vulnerability climate change threats result in more positive evaluation of protection behavior and higher acceptance of conservation practices (Keshavarz \& Karami, 2016).

If farmers consider strategies as not effective, they are less likely to adopt and practice as better response mechanism. This is due to the fact that climatic conditions, soil and other factors vary across different agro ecologies, influencing farmers' perceptions of climate change and their decisions to adapt (Deressa, 2008). Perceived cost of adaptation and mitigation strategies are an imperative factor, which influences the decision of farmers to react to climate change threats (Bockarjova \& Steg, 2014). Strategies such as irrigation and fuel wood conservation technologies (such as stove, solar panel and biogas) for instance were perceived as costly for farmers in terms of finance, labor and time. Response costs such as financial, time, effort and emotional costs represent all perceived costs connected to protective actions. Wealth and human capital are important predictors of adaptation practices among farmers (Ali \& Erenstein, 2017b). Response costs and thus the time and financial barriers associated with protection measures are also found to be considerably (Keshavarz \& Karami, 2016). As compared to other strategies such as soil conservation and agricultural intensification, irrigation is less practiced by the farmers. Farmers' perception of changes in the climate positively influences their protection motivation, while the cost of adaptation measures negatively affects their protection motivation (Bagagnan et al., 2019).

\section{Conclusion and recommendations}

Climate change remains a global threat, which affects the global population though unevenly. Smallholder farmers are more susceptible than any other segments due to overdependence on rained agriculture. This study examined the determinants of climate change taking in Protection Motivation Theory. The main notion is considering climate change as a threat and assessing the subjective understanding of farmers about the occurrence, severity and vulnerability to climate change threat thereby take adjustments to avert risks attached to climate change. Farmers in study area recognized that climate change is real and occurring. For smallholder farmers, the effect of climate change was found to transcend generation due to its impact on precious asset such as land from which rural people make their living. Cognizant of climate change threat, rural people practice adaptation and mitigation practices, which they consider feasible to their context. Perceived self-efficacy, response efficacy and cost attached to adaptation and mitigation strategies were found to determine farmers' motivation to respond to climate change threat. Farmers are less likely to adopt practice, which they consider they are 
unable to practice, for instance adopting fuel conservation technologies, which are perceived costly and complex given a local expertise. On the other hand, adaptation practices such as soil and water conservation were considered effective and manageable to the level of farmers and therefore widely practiced in the community. Thus, human capital and financial constraints hinders climate change adaptations.

The contribution of this study is twofold: First, shifting the study of climate change from structural determinants such as agro-ecology, policy and macro economy to micro behavioral determinants influencing climate change adaptation strategies. The second relevance is to assess the gap between the top-down adaptation and mitigation strategies and the perceived relevance and effectiveness of the rural community. Farmers' perception of severity of climate change risks may not necessarily mean they are able to practice it. Farmers balance between threat appraisal and coping. In this study farmers understood the threat posed by climate change but not all farmers were able to adapt to or mitigate climate change. Therefore, economic empowerment and human capital investment are important in order to enable farmers to adopt and practice climate change adaptation and mitigation strategies. Some strategies are more feasible than other rural development strategies to assess the need of farmers and pursue context specific adaptation strategies. Field visit and experience sharing among different successful watersheds would enhance self-efficacy and response efficacy among farmers. Reducing vulnerability of farming community demands building sustainable resilient system through synergizing local knowledge and emerging climate change adaptation discourse.

\section{REFERENCES}

Abrha, M. G., \& Simhadri, S. (2015a). Local climate trends and farmers' perceptions in Southern Tigray, Northern Ethiopia. American Journal of Environmental Sciences, 11(4), 262-277. https://doi.org/10.3844/ajessp.2015.262.277

Abrha, M. G., \& Simhadri, S. (2015b). Local Climate Trends and Farmers' Perceptions in Southern. https://doi.org/10.3844/ajessp.2015.262.277

Aizebeokhai, A. P. (2009). Global warming and climate change: Realities, uncertainties and measures, 4(13), 868-879.

Ajuang, C. O., Abuom, P. O., Bosire, E. K., Dida, G. O., \& Anyona, D. N. (2016). Determinants of climate change awareness level in upper Nyakach Division, Kisumu County, Kenya. Springer Plus, 5(1). https://doi.org/10.1186/s40064-016-2699-y

Alam, G. M. M., Alam, K., \& Mushtaq, S. (2017). Climate change perceptions and local adaptation strategies of hazard-prone rural households in Bangladesh. Climate Risk Management, 17, 52-63. https://doi.org/10.1016/j.crm.2017.06.006

Ali, A., \& Erenstein, O. (2017). Assessing farmer use of climate change adaptation practices and impacts on food security and poverty in Pakistan. Climate Risk Management, 16, 183-194. https://doi.org/10.1016/j.crm.2016.12.001

Amare, A., \& Simane, B. (2017). Determinants of smallholder farmers' decision to adopt adaptation options to climate change and variability in the Muger Sub basin of the Upper Blue Nile basin of Ethiopia. Agriculture and Food Security, 6(1), 1-20. https://doi.org/10.1186/s40066-017-0144-2

Amare, A., \& Simane, B. (2018). Does adaptation to climate change and variability provide household food security? Evidence from Muger sub-basin of the upper Blue-Nile, Ethiopia. Ecological Processes, 7(1). https://doi.org/10.1186/s13717-018-0124-x

Asayehegn, K., Temple, L., Sanchez, B., \& Iglesias, A. (2017). Perception of climate change and farm level adaptation choices in central Kenya. Cahiers Agricultures, 26(2), 1-10. https://doi.org/10.1051/cagri/2017007

Asrat, P., \& Simane, B. (2018a). Farmers' perception of climate change and adaptation strategies in the Dabus watershed, North-West Ethiopia. Ecological Processes, 7(1). https://doi.org/10.1186/s13717-018-01188

Asrat, P., \& Simane, B. (2018b). Farmers' perception of climate change and adaptation strategies in the Dabus.

Bagagnan, A. R., Ouedraogo, I., Fonta, W. M., \& Sowe, M. (2019). Can Protection Motivation Theory Explain Farmers' Adaptation to Climate Change Decision Making in The Gambia. Climate, 7(13), 1-14. https://doi.org/10.3390/cli7010013 
Belay, A., Recha, J. W., Woldeamanuel, T., \& Morton, J. F. (2017). Smallholder farmers' adaptation to climate change and determinants of their adaptation decisions in the Central Rift Valley of Ethiopia. Agriculture and Food Security, 6(1), 1-13. https://doi.org/10.1186/s40066-017-0100-1

Berhanu, W., \& Beyene, F. (2015). Climate variability and household adaptation strategies in southern Ethiopia. Sustainability (Switzerland), 7(6), 6353-6375. https://doi.org/10.3390/su7066353

Berhe, M., Hoag, D., Tesfay, G., Tadesse, T., Oniki, S., Kagatsume, M., \& Keske, C. M. H. (2017). The effects of adaptation to climate change on income of households in rural Ethiopia. Pastoralism, 7(1). https://doi.org/10.1186/s13570-017-0084-2

Bockarjova, M., \& Steg, L. (2014). Can Protection Motivation Theory predict pro-environmental behavior? Explaining the adoption of electric vehicles in the Netherlands. Global Environmental Change, 28, 276288. https://doi.org/10.1016/j.gloenvcha.2014.06.010

CRGE. 2011. Green Economy Strategy, the Federal Democratic Republic of Ethiopia, Addis Ababa, Ethiopia.

Debela, N., Mohammed, C., Bridle, K., Corkrey, R., \& Mcneil, D. (2015). Perception of climate change and its impact by smallholders in pastoral / agropastoral systems of Borana, South Ethiopia, SpringerPlus 4, https://doi.org/10.1186/s40064-015-1012-9

Deressa, T. (2008). Analyzing the Determinants of Farmers' Choice of Adaptation Methods and Perceptions of Climate Change in the Nile Basin of Ethiopia. Global Environmental, (September), 36. https://doi.org/10.1016/j.gloenvcha.2009.01.002

Elum, Z. A., Modise, D. M., \& Marr, A. (2016). Farmers perception of climate change and responsive strategies in three selected provinces of South Africa. Climate Risk Management. https://doi.org/10.1016/j.crm.2016.11.001

Erena, N. (2016). Analysis on Determinants of Adaptation Options to Climate Change of Maize Smallholder Farmers in the South Eastern part of Ethiopia, Journal of Natural Sciences Research, 6(17), 32-50.

Falco, S. Di. (n.d.). What Adaptation to Climate Change? Evidence from the Nile Basin, Ethiopia 1, 1-23.

Feleke, F. B., Berhe, M., Gebru, G., \& Hoag, D. (2016). Determinants of adaptation choices to climate change by sheep and goat farmers in Northern Ethiopia: the case of Southern and Central Tigray, Ethiopia. SpringerPlus. https://doi.org/10.1186/s40064-016-3042-3

Harun, R., Jamalani, M. A., Elawad, R. E., \& Fallah, M. (2014). Perception of and adaptation to climate change by farmers in the semi-arid zone of North-eastern Nigeria, Journal of Environmental Science, Toxicology and Food Technology (IOSR-JESTFT), 8(11), 52-57.

Hunt, A., \& Watkiss, P. (2011). Climate change impacts and adaptation in cities: A review of the literature. Climatic Change, 104(1), 13-49. https://doi.org/10.1007/s10584-010-9975-6

Huq, N., Hugé, J., Boon, E., \& Gain, A. K. (2015). Climate Change Impacts in Agricultural Communities in Rural Areas of Coastal Bangladesh: A Tale of Many Stories, 8437-8460. https://doi.org/10.3390/su7078437

Ihemezie, E. J., Onunka, C. N., \& Nnaji, A. P. (2018). Drivers and socioeconomic factors influencing individual and household adaptation to climate change: A case study of residents of Leeds, UK, 10(September), 279-291. https://doi.org/10.5897/JDAE2018.0956

Janmaimool, P. (2017). Application of Protection Motivation Theory to Investigate Sustainable Waste Management Behaviors. Sustainability, 9(1079), 1-16. https://doi.org/10.3390/su9071079

Keshavarz, M., \& Karami, E. (2016). Farmers' pro-environmental behavior under drought: Application of protection motivation theory. Journal of Arid Environments, 127, 128-136. https://doi.org/10.1016/j.jaridenv.2015.11.010

Kibue, G. W., Pan, G., Joseph, S., Xiaoyu, L., Jufeng, Z., Zhang, X., \& Li, L. (2015). More than two decades of climate change alarm: Farmers knowledge, attitudes and perceptions. African Journal of Agricultural Research, 10(27), 2617-2625. https://doi.org/10.5897/AJAR2013.8350

Limantol, A. M., Keith, B. E., Azabre, B. A., \& Lennartz, B. (2016). Farmers' perception and adaptation practice to climate variability and change: a case study of the Vea catchment in Ghana. SpringerPlus. Springer International Publishing. https://doi.org/10.1186/s40064-016-2433-9

Locatelli, B. (2011). Synergies between adaptation and mitigation in a nutshell. Cobam, 8(6). Retrieved from https://www.cifor.org/fileadmin/fileupload/cobam/ENGLISH-Definitions\%26ConceptualFramework .pdf

M.M, B. (2014). Perception of and adaptation to climate change by farmers in the semi-arid zone of North-eastern Nigeria. IOSR Journal of Environmental Science, Toxicology and Food Technology, 8(11), 52-57. https://doi.org/10.9790/2402-081115257

Mubaya, C. P., \& Mafongoya, P. (2017). Local-level climate change adaptation decision-making and livelihoods in semi-arid areas in Zimbabwe. Environment, Development and Sustainability, 19(6). https://doi.org/10.1007/s10668-016-9861-0

Osberghaus, D., Finkel, E., Pohl, M., Osberghaus, D., Finkel, E., \& Pohl, M. (2010). Individual Adaptation to Climate Change: The Role of Information and Perceived Risk (No. Dis cus si on Paper No. 10-061 
Individual). Mannheim, Germany.

Rahmstorf, S., Foster, G., \& Cahill, N. (2017). Global temperature evolution: recent trends and some pitfalls.

Rogers, R. W. (1983). Protection Motivation and Self-Efficacy: A Revised Theory of Fear Appeals and Attitude Change. Journal of Experimental Pyschology, 469-479.

Shikuku, K. M., Winowiecki, L., Twyman, J., Eitzinger, A., Perez, J. G., Mwongera, C., \& Läderach, P. (2017). Climate Risk Management Smallholder farmers' attitudes and determinants of adaptation to climate risks in East Africa. Climate Risk Management, 16, 234-245. https://doi.org/10.1016/j.crm.2017.03.001

Suryabhagavan, K. V. (2017). GIS-based climate variability and drought characterization in Ethiopia over three decades. Weather and Climate Extremes, 15(November 2016), 11-23. https://doi.org/10.1016/j.wace.2016.11.005

Tarigan, S., \& Faqih, A. (2019). Impact of Changes In Climate And Land Use On The Future Streamflow Fluctuation: Case Study Merangin Tembesi Watershed, Jambi Province, Indonesia, 9(1), 181-189. https://doi.org/10.29244/jps1.9.1.181-189

Tazeze, A., Haji, J., \& Assistance, M. K. (2012). Climate Change Adaptation Strategies of Smallholder Farmers: The Case of Babilie District, East Harerghe Zone of Oromia Regional State of Ethiopia, Journal of Economics and Sustainable Development, 3(14), 1-13.

Temesgen, D., Yehualashet, H., \& Rajan, D. S. (2014). Climate change adaptations of smallholder farmers in South Eastern Ethiopia, 6(11), 354-366. https://doi.org/10.5897/JAERD14.0577

Tesso, G., Emana, B., \& Ketema, M. (2012). Analysis of vulnerability and resilience to climate change induced shocks in North Shewa, Ethiopia. Agricultural Sciences, 03(06), 871-888. https://doi.org/10.4236/as.2012.36106

Wako, G., Tadesse, M., \& Angassa, A. (2017). Camel management as an adaptive strategy to climate change by pastoralists in southern Ethiopia. Ecological Processes, 6(1). https://doi.org/10.1186/s13717-017-00935

Yéo, W. E., Goula, B. T. A., Diekkrüger, B., \& Afouda, A. (2016). Vulnerability and adaptation to climate change in the Comoe River Basin (West Africa). SpringerPlus, 5(1). https://doi.org/10.1186/s40064-016-2491-z

Yesuf, M. (2008). Analyzing the Determinants of Farmers' Choice of Adaptation Methods and Perceptions of Climate Change in the Nile Basin of Ethiopia, (September). 